\title{
UJI DAYA BUNUH EKSTRAK BIJI SIRSAK (Annona muricata) TERHADAP LARVA KUBIS Plutella xylostella (Linn.) (LEPIDOPTERA: PLUTELLIDAE)
}

\author{
Eva Lienneke Baideng ${ }^{1)}$ \\ ${ }^{1)}$ Program Studi Biologi, FMIPA Universitas Sam Ratulangi Manado \\ Email: eva.baideng@yahoo.co.id
}

\begin{abstract}
ABSTRAK
Penelitian terhadap uji daya bunuh ekstrak biji sirsak (Annona muricata) terhadap larva kubis Plutella xylostella dilakukan untuk mengetahui uji daya bunuh beberapa konsentrasi ekstrak biji sirsak terhadap larva Plutella xylostella. Manfaat penelitian adalah untuk memberikan informasi daya bunuh dari ekstrak biji sirsak terhadap larva $P$. xylostella sehingga dapat digunakan dalam pengendalian hama tersebut. Penelitian dilaksanakan di desa Rurukan Kota Tomohon, yang berlangsung selama 3 bulan. Metode penelitian yang digunakan adalah Rancangan Acak Lengkap (RAL), yang terdiri dari 6 perlakuan dan tiap perlakuan terdiri dari tiga ulangan. Hasil penelitian menunjukkan bahwa persentase kematian larva meningkat seiring dengan meningkatnya konsentrasi ekstrak biji sirsak yang disemprotkan yaitu $10 \mathrm{~g} / \mathrm{l}, 20 \mathrm{~g} / \mathrm{l}, 30 \mathrm{~g} / \mathrm{l}, 40 \mathrm{~g} / \mathrm{l}$ dan $50 \mathrm{~g} / \mathrm{l}$. Beberapa larva yang belum mati pada stadia ini dan masih hidup hingga pada stadia pupa, persentase mortalitasnya tidak meningkat seiring dengan meningkatnya konsentrasi ekstrak biji sirsak yang diaplikasikan, yakni secara berurutan 30g/l (11,11\%), 10g/l (13,33\%), 50g/l (14,44\%), $20 \mathrm{~g} / \mathrm{l}(16,67 \%)$ dan $40 \mathrm{~g} / \mathrm{l}(16,67 \%)$. Total persentase mortalitas larva dan pupa meningkat seiring dengan meningkatnya konsentrasi ekstrak biji sirsak yang disemprotkan. Konsentrasi ekstrak biji sirsak sebesar 50g/l sudah cukup baik digunakan sebagai insektisida botani dalam mengendalikan populasi hama $P$. xylostella, karena pada konsentrasi ini efektif mematikan sebesar $96,78 \%$ populasi serangga yang diuji.
\end{abstract}

Kata kunci: biji sirsak, Plutella xylostella, kubis

\section{TEST POWER KILL THE SEED EXTRACT SOURSOP (Annona muricata) ON CABBAGE LARVAE Plutella xylostella (Linn.) (LEPIDOPTERA: PLUTELLIDAE)}

\begin{abstract}
Research on the test of the power to kill the seed extract of soursop (Annona muricata) to larvae of the cabbage Plutella xylostella test is performed to determine the power to kill some seed extract concentration of soursop against Plutella xylostella larvae. Benefits of the research is to provide information on the killing power of soursop seed extract against $P$. xylostella larvae so that it can be used. In the pest control. Research conducted at the village Rurukan Tomohon, which lasted for three months. The method used is Completely Random Design (CRD), which consists of 6 treatments and each treatment consisted of three replication. The results showed that the percentage of larval mortality increases with increasing concentration of soursop seed extract that is sprayed is $10 \mathrm{~g} / 1,20 \mathrm{~g} / \mathrm{l}, 30 \mathrm{~g} / 1,40 \mathrm{~g} / 1$ and $50 \mathrm{~g} / 1$. Some larvae are not dead at this stage and still live up to the pupal stage, the percentage of mortality was not increased with increasing concentration of soursop seed extract is applied, ie sequentially $30 \mathrm{~g} / 1(11.11 \%), 10 \mathrm{~g} /$ $1(13.33 \%), 50 \mathrm{~g} / 1(14.44 \%), 20 \mathrm{~g} / 1(16.67 \%)$ and 40g / 1 (16.67\%). Total percentage mortality of larvae and pupae increased with increasing concentration of soursop seed extract is sprayed. Concentration of soursop seed extract of $50 \mathrm{~g} / \mathrm{l}$ is good enough to use as a botanical insecticide to control the pest population of $P$. xylostella, because at this concentration amounted to $96.78 \%$ effective lethal insect populations tested.
\end{abstract}

Keywords: soursop seed, Plutella xylostella, cabbage. 


\section{PENDAHULUAN}

Kebutuhan masyarakat terhadap bahan pangan yang bergizi dan aman terhadap residu pestisida yang berlebihan dewasa ini, dan dimasa-masa mendatang akan meningkat terus secara proporsional, sejalan dengan semakin bertambahnya jumlah penduduk, meningkatnya tingkat pendidikan, pengetahuan, dan kesadaran terhadap pangan yang aman bagi kesehatan tubuh.

Sulawesi Utara merupakan daerah yang memiliki pertanaman sayuran yang cukup besar di kawasan Indonesia Bagian Timur. Luas tanam tanaman kubis di Sulawesi Utara adalah $5.908 .474 \mathrm{~m}^{2}$ (BPS Sulut, 2015). Namun rata-rata produksi yang dihasilkan masih rendah. Rendahnya produksi kubis di Sulawesi Utara disebabkan oleh sistem bercocok tanam yang masih bersifat konvensional dan tingkat serangan hama terutama Plutella xylostella dan Crocidolomia binotalis yang cukup tinggi.

Sampai saat ini titik berat pengendalian hama tanaman kubis di Indonesia, khususnya Sulawesi Utara masih ditujukan pada pengendalian secara kimia. Pengendalian secara kimia dapat menurunkan populasi hama tapi hanya untuk sementara waktu. Sembel $d k k$ (1990) melaporkan bahwa penggunaan insektisida untuk pengendalian hama sayur-sayuran terutama tanaman petsai dan kubis ternyata telah dilakukan petani di Sulawesi Utara secara berlebihan baik dari segi dosis maupun jumlah perlakuan. Cara pengendalian kimia ini mengakibatkan terjadinya kontaminasi zat racun pada produksi sayuran, serta pencemaran terhadap lingkungan (air, tanah, dan udara).

Penggunaan bahan kimia alami dari tanaman bioaktif tidak menimbulkan pencemaran lingkungan, baik tanah, air dan udara, tidak menimbulkan residu di alam, mudah dilaksanakan serta biaya pelaksanaan yang relatif murah (Sastroutomo, 1992). Oleh karena itu sangat penting untuk menggali potensi sumber daya hayati bahan aktif alami untuk digunakan sebagai bahan pengendali hama. Salah satu tanaman yang dapat dimanfaatkan adalah tanaman sirsak (Annona muricata), dimana di daerah Sulawesi Utara tanaman ini banyak ditemukan sebagai tanaman pekarangan.
Kandungan fitokimia tanaman ini adalah asetogenin, alkaloid, kuinolina, isokuinolina, tanin, kumarin, prosianidin, flavonoid, amil kaproat (Lim, 2012). Trisnowati, Dkk (2012) mengamati bahwa ekstrak daun sirsak mulai konsentrasi 2,5\% mempunyai aktivitas anti makan dari larva $S$. litura instar V

Penelitian ini bertujuan untuk menguji daya bunuh beberapa konsentrasi ekstrak biji sirsak terhadap larva P.xylostella.

\section{BAHAN DAN METODE}

Penelitian telah dilaksanakan di desa Rurukan Kecamatan Tomohon dan desa Tempok Kecamatan Tompaso Kabupaten Minahasa, yang beriangsung selama 3 bulan.

Penelitian dilaksanakan pada kondisi laboratorium. Rancangan percobaan yang digunakan adalah Acak Lengkap. Sebagai perlakuan yaitu konsentrasi $0 \mathrm{~g} / \mathrm{l}, 10 \mathrm{~g} / \mathrm{l}, 20$ g/l, 30 g/l, 40 (7/1, SO g/1. Setiap perlakuan diulang sebanyak tiga kali.

\section{Perbanyakan Larva Plutellaxylostella}

Larva-larva $\quad P . \quad$ xylostella dikumpulkan di sekitar Kecamatan Tompaso dan dipelihara sampai menjadi pupa. Diambil sebanyak 200 ekor pupa $P$. xylostella dari kurungan pemeliharaan larva dan dimasukkan ke dalam stoples pemeliharaan. Pupa yang berhasil menjadi imago dipindahkan ke dalam kurungan yang didaiamnya sudah di letakkan 8 pot tanaman kubis sebagai tempat imago meletakkan telurnya selama 1 hari. Sebagai makanan dari imago, diberi larutan inadu $30 \%$ yang dioleskan pada lembaran plastik yang digantungkan dalam kurungan. Setelah telur-telur P. xylostella menetas menjadi larva maka larva-larva instar ketiga siap digunakan untuk pengujian. Digunakan larva instar ketiga karena pada instar irii larva aktif merusak. Larva-larva tersebut langsung dipindahkan ke dalam cawan petri dan dipuasakan selama 12 jam kemudian langsung diaplikasi.

\section{Penyediaan Ekstrak Biji Sirsak}

Biji sirsak yang digunakan berasal dari buah yang telah matang dan bijinya berwarna hitam. Biji dikeringudarakan terlebih dahulu 
selama 7 hari dan kemudian dikupas untuk diambil isinya. Isi biji sirsak tersebut dihaluskan dengan menggunakan blender kering hingga menjadi serbuk. Untuk memperoleh konsentrasi ekstrak $10 \mathrm{~g} / \mathrm{l}$ maka diambil 10 gram biji sirsak dan ditambahkan 1 liter aquades yang mengandung 0,50 gram deterjen bubuk dan diblender selama 30 menit, konsentrasi ekstrak $20 \mathrm{~g} / 1$ maka diambil 20 gram biji sirsak dan ditambahkan 1 liter aquades yang mengandung 0,50 gram deterjen bubuk dan diblender selama $6 \mathrm{x}$ 5 menit. Demikian pula dengan konsentrasi ekstrak 30 g/l, 40 g/1 dan 50 g/l. Selanjutnya ekstrak disaring dengan menggunakan kain tetron, dimasukkan dalam wadah yang tertutup.

\section{Aplikasi Ekstrak Biji Sirsak}

Aplikasi ekstrak biji sirsak pada serangga uji dilakukan dalam cawan petri. Daun kubis dibuat membentuk cakram (bundaran) dengan diameter yang sama dengan ukuran cawan petri. Suspensi ekstrak dengan konsentrasi 10 g/l, 20 g/l, 30 $\mathrm{g} / 1,40 \mathrm{~g} / \mathrm{l}$ dan $50 \mathrm{~g} / 1$ disemprotkan dengan hand sprayer, kemudian daun yang telah disemprot dikeringudarakan. Daun kubis tersebut diletakkan pada bagian dasar cawan petri yang dialasi kertas tissue. Setiap cawan petri dimasukkan 30 larva uji kemudian ditutup menggunakan kain kassa agar larva tidak keluar. Setelah 24 jam, daun sisa diganti dengan daun tanpa perlakuan, dan larva terus dipelihara hingga menjadi imago.

\section{Pengamatan}

Hal-hal yang diamati dalam penelitian ini adalah mortalitas larva dan pupa serta gejala kematiannya.

\section{Analisis Data}

Data mortalitas terlebih dahulu di transformasi ke Arcsin $\mathrm{X}^{1 / 2}$ kemudian dianalisis dengan analisis keragaman dan dilanjutkan sampai Uji Beda Nyata Terkecil.

\section{HASIL DAN PEMBAHASAN}

Hasil pengamatan mortalitas larva Plutella xylostella sesudah diaplikasi dengan ekstrak biji sirsak pada beberapa konsentrasi yaitu $10 \mathrm{~g} / 1,20$ $\mathrm{g} / 1, \quad 30 \mathrm{~g} / 1,40 \mathrm{~g} / 1,50$ 0/1 dan kontrol menunjukkan angka yang berbeda. Bari hasil analisis ragam (Lampiran 5) menunjukkan bahwa antara perlakuan terdapat perbedaan sangat nyata. Untuk menentukan perlakuan mana yang sating berbeda tersebut, dioakai uji BNT 5\%. Rata- rata persentase mortalitas larva $P$. xylostella yang diaplikasikan dengan berbagai konsentrasi ekstrak biji sirsak dapat dilihat pada Tabel 1 .

Tabel 1. Rata-rata Mortalitas Larva P. xylostella yang Diberi Perlakuan Ekstrak Eiji Sirsak dengan Beberapa Konsentrasi.

\begin{tabular}{|rr|rrr|}
\hline $\begin{array}{c}\text { Konsentrasi } \\
\text { Ekstrak Biji Sirsak }\end{array}$ & $\begin{array}{r}\text { Rata-rata Mortalitas } \\
\text { Larva(\%) }\end{array}$ \\
\hline Kontrol & & {$[8,89]$} & 17,29 & $\mathrm{a}^{*}$ \\
10 & $\mathrm{~g} / 1$ & {$[23,34]$} & 26,59 & $\mathrm{~b}$ \\
20 & $\mathrm{~g} / 1$ & {$[37,78]$} & 37,92 & $\mathrm{c}$ \\
30 & $\mathrm{~g} / 1$ & {$[57,78]$} & 49,52 & $\mathrm{~d}$ \\
40 & $\mathrm{~g} / 1$ & {$[72,22]$} & 58,32 & $\mathrm{e}$ \\
50 & $\mathrm{~g} / 1$ & {$[82,22]$} & 65,20 & $\mathrm{f}$ \\
\hline
\end{tabular}

$[\ldots]=$ Angka mortalitas riil

* = Angka yang diikuti oleh huruf yang sama tidak menunjukkan perbedaan

Dari tabel 1 terlihat bahwa ekstrak biji sirsak memberikan pengaruh terhadap mortalitas larva $P$. xylostella. Persentase kematian larva meningkat seiring dengan meningkatnya konsentrasi ekstrak biji sirsak yang disemprotkan. Hasil ini kemungkinan berkaitan dengan sifat senyawa acetogenin yang dikandung sirsak, yakni bila konsentrasi acetogenin yang diaplikasikan rendah maka senyawa ini menjadi racun perut (bisa juga mematikan), namun pada konsentrasi sebaliknya menyebabkan serangga tidak mau makan (Anonim 1994). Jadi makin tinggi konsentrasi ekstrak biji sirsak yang diaplikasikan menyebabkan makin banyak larva yang tidak mau 
makan, akibatnya makin banyak pula larva yang mati. Selain itu, menurut Prijono (1994) senyawa acetogenin dari tanaman Annonaceae memiliki efek kontak yang cukup baik terhadap serangga dari beberapa ordo misalnya ordo Lepidoptera. Hal ini sesuai dengan pengamatan bahwa semakin tinggi konsentrasi ekstrak biji sirsak yang disemprotkan pada larva $P$. xylostella maka makin banyak pula racun yang terkontak pada kulit serangga. Dengan demikian semakin tinggi ekstrak maka kematian larva $P$. xylostella makin banyak.

Larva $P$. xylostella instar tiga sesudah disemprot dengan berbagai level konsentrasi ekstrak biji sirsak, pada waktu tertentu mulai nampak sejumlah larva yang mati. Namun ada beberapa larva yang belum mati pada stadia tersebut dan masih hidup hingga pada stadia pupa. Rata-rata persentase mortalitas pupa tersebut dapat dilihat pada Tabel 2.

Tabel 2. Rata-rata Mortalitas Pupa P. xylostella yang merupakan kelanjutan dari aplikasi pada Larva

\begin{tabular}{|c|c|c|c|c|}
\hline \multicolumn{5}{|c|}{$\begin{array}{l}\text { Konsentrasi Ekstrak Biji Rata-rata Mortalitas Pupa Sirsak } \\
\qquad(\%)\end{array}$} \\
\hline & Kontrol & {$[0,00]$} & 0,00 & $a^{*}$ \\
\hline & $10 \mathrm{~g} / 1$ & {$[13,33]$} & 21,32 & b \\
\hline & $20 \mathrm{~g} / 1$ & {$[16,67]$} & 24,02 & b \\
\hline & $30 \mathrm{~g} / 1$ & {$[11,11]$} & 13,81 & b \\
\hline & $40 \mathrm{~g} / 1$ & {$[16,67]$} & 24,02 & b \\
\hline & $50 \mathrm{~g} / 1$ & {$[14,44]$} & 18,97 & b \\
\hline BNT & $5 \%$ & & 12,01 & \\
\hline
\end{tabular}

Dari tabel 2 terlihat bahwa efek ekstrak biji sirsak terhadap pupa berbeda dengan pada larva (Tabel 2). Kelihatan bahwa persentase mortalitas pupa tidak meningkat seiring dengan meningkatnya konsentrasi ekstrak biji sirsak yang diaplikasikan. Dalam kasus ini nampak bahwa setelah memasuki stadia pupa, aktivitas biokirnia karena aplikasi ekstrak biji sirsak sejak dari stadia larva sangat beragam. Fenomena ini mungkin terjadi karena aktivitas metabolisme stadia pupa yang khas. Menurut Wigglesworth
(1974), menjelang akhir stadia larva banyak sekali cadangan glikogen yang terakumulasi, kadang-kadang protein diperlukan dalam jumlah besar untuk pembentukan kokon. Dengan demikian ada kemungkinan bahwa aktivitas biokimia banyak diarahkan untuk membentuk senyawa-senyawa tersebut, sedang aktivitas metabolisme untuk menetralisir racun di dalam tubuhnya menurun. Dalam hal ini mungkin setiap individu (larva) berbeda kegiatan metabolisme untuk mendetoksifikasi kadar racun yang masuk, sehingga nampak fenomena tersebut. Dengan demikian, sebagian larva yang masih bertahan hidup namun mati sewaktu pada stadia Pupa, paling banyak ditemukan pada yang diaplikasikan dengan 40 g/1 dan 20 g/1 ekstrak biji sirsak yaitu masing-masin:- 24,02\%. Tingkat mortalitas ini tidak berbeda nyata dengan aplikasi ekstrak biji sirsak 10 g/l, 30 g/1 dan $50 \mathrm{~g} / \mathrm{l}$, tetapi hanya berbeda nyata dengan kontrol $(0 \%)$.

Data persentase mortalitas larva ditambah dengan persentase mortalitas pupa (yang belum mati ketika masih stadia larva) karena perlakuan beberapa konsentrasi ekstrak biji sirsak (Lampiran 4), mengindikasikan bahwa ekstrak biji sirsak merupakan tanaman bioaktif yang balk digunakan dalam mengendalikan serangga hama $P$. xylostella. Dikemukakan demikian, karena pada konsentrasi 50 g/1 sudah mampu mengendalikan populasi hama P. xylostella secara keseluruhan dari larva sampai pupa yaitu 96,78\%. Hal ini sesuai dengan yang dikemukakan oleh Prijono (1994), bahwa syarat batas pengujian ekstrak tanaman bioaktif menggunakan konsentrasi ekstrak tertinggi yaitu 50 gram bahan tanaman per liter air. Karena berdasarkan pengalaman, konsentrasi tersebut merupakan batas kelayekan untuk penggunaan ekstrak di lapang. Ekstrak yang tidak efektif pada konsentrasi $50 \mathrm{~g} / 1$ tidak perlu diteliti lebih lanjut. Ekstrak biji sirsak $50 \quad \mathrm{~g} / 1$ efektif untuk mengendalikan hama $P$. xylostella karena perlakuan dengan konsentrasi ekstrak biji sirsak tersebut dapat mengakibatkan kematian hingga 96,78\% dari keseluruhan populasi serangga uji. Hal ini berarti sesuai 
dengan yang dikemukakan oleh Prijono (1994) bahwa suatu ekstrak dikatakan efektif bila perlakuan dengan ekstrak tersebut dapat mengakibatkan tingkat kematian $90 \%$.

Dalam konteks mengenai hubungan antara masingmasing konsentrasi ekstrak biji sirsak dengan jumlah larva yang mati, dan larva yang masih hidup namun mati sesudah stadia pupa, dihubungkan dengan kisaran waktu tertentu menunjukkan angka kematian tertinggi 6 jam setelah aplikasi,seperti yang terlihat pada Tabel 3.

Tabel 3. Rata-rata Mortalitas Larva dan Pupa Plutella xylostella setelah Aplikasi dengan Waktu Pengamatan Kelipatan 6 jam

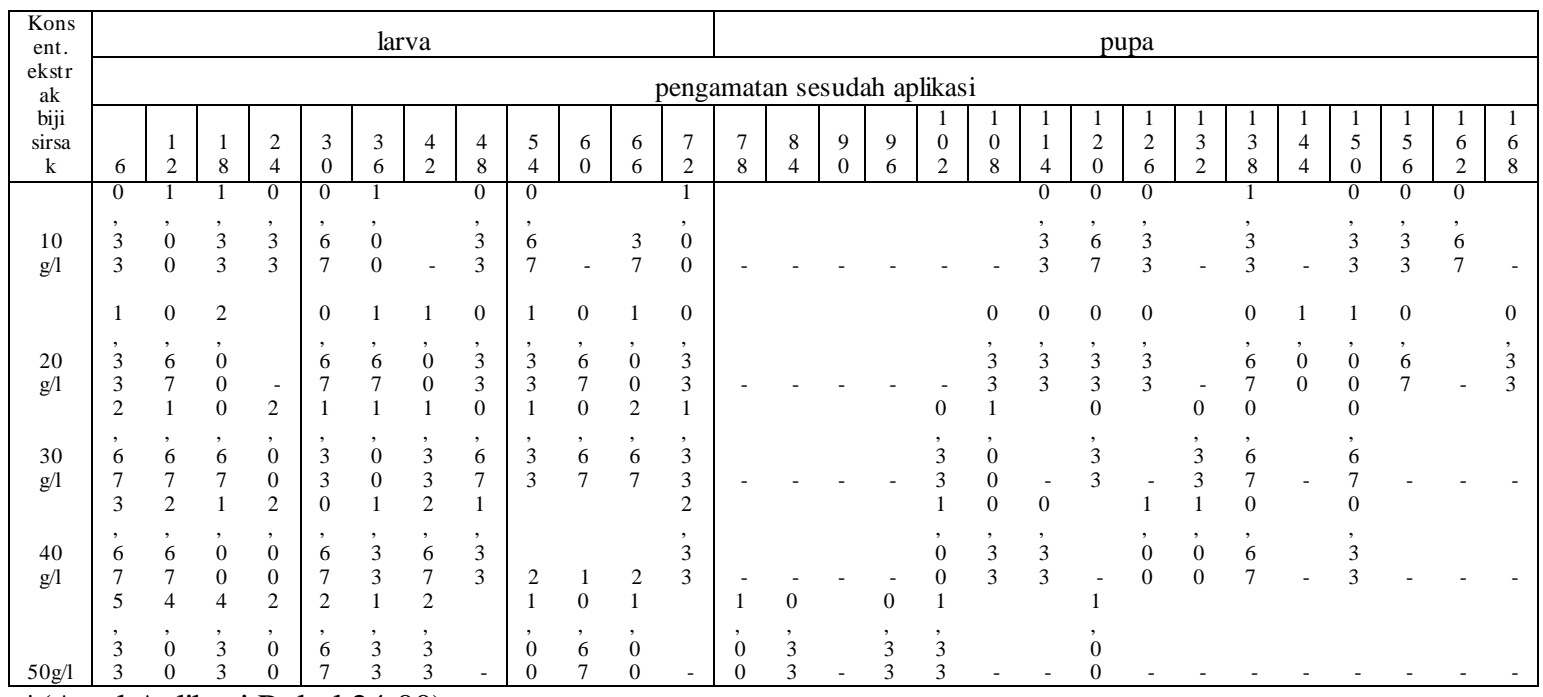

*(Awal Aplikasi Pukul 24.00)

Dari Tabel 3 nampak bahwa sesudah 6 jam pengaplikasian, jumlah larva yang mati meningkat berbarengan dengan meningkatnya level konsentrasi ekstrak biji sirsak, dan pada periode inilah yang paling banyak jumlah yang mati; kemudian diikuti kelipatan 6 jam berikutnya hingga pada 30 jam sesudah aplikasi, angka kematian larva makin menurun dan kelipatan 6 jam sesudah 30 jam sampai ke72 jam angka kematian berfluktuasi. Angka kematian tertinggi pada 6 jam pertama kemudian selanjutnya menurun hingga pada waktu tertentu. Penyebab terjadinya mungkin berkaitan dengan keragaman genetik setiap larva. Menurut Corbet (1984) bahwa setiap individu dalam suatu populasiberbeda cara dan kecepatan menetralisir toksin, selain itu berbeda pula tempat yang menjadi sasaran suatu racun. Jadi karena setiap larva berbeda kepekaan dan kecepatan menetralisir racun yang terkontak,maka pantaslah kalau terjadi banyak kematian larva pada jam-jam awal sesudah penyemprotan. Sedang angka kematiannya berfluktuasi pada kisaran waktu tersebut kemungkinan berhubungan dengan variabilitas genetik seperti yang dikemukakan sebelumnya, dalam hal ini ada yang mampu bertahan hingga batas waktu tertentu, sedang yang lain tidak.

Beberapa larva yang masih mampu bertahan hidup hingga mencapai stadia pupa namun pada akhirnya mati, bervariasi pula dalam hal waktu matinya (Tabel 3). Nampak pada tabel tersebut bahwa semakin tinggi konsentrasi ekstrak biji sirsak yang diaplikasikan, semakin cepat mengalami kematian, artinya begitu memasuki stadia pupa, tidak lama kemudian mati. Secara logis hal ini wajar terjadi demikian sebab semakin tinggi kadar racun di dalam tubuh organisme, makin sulit organisme mengarahkan aktivitas metabolismenya untuk menghambat, mengurangi, atau menetralisir racun yang ada di dalamnya; sehingga memungkinkan mengalami kematian lebih cepat. 
Berdasarkan pengamatan, ternyata kematian larva $P$. xylostella tidak semuanya terjadi secara langsung setelah perlakuan tetapi kematian terjadi berangsur-angsur sampai stadia pupa. Hal ini memperlihatkan bahwa ekstrak biji sirsak lebih bersifat menghambat perkembangan serangga daripada mematikan secara langsung.

Gejala yang dapat dilihat dari larva P.xylostella yang mengalami kematian setelah disemprot dengan beberapa level konsentrasi ekstrak biji sirsak adalah larvalarva tersebut tidak aktif bergerak dan kurang makan. Larva-larva yang mati terjadi perubahan warna menjadi agak hitam sedangkan pupa yang mati ukurannya mengecil dan terjadi perubahan warna menjadi kehitaman.

\section{KESIMPULAN}

Persentase mortalitas P.xylostella meningkat seiring dengan konsentrasi ekstrak biji sirsak yang diaplikasikan. Konsentrasi ekstrak biji sirsak $50 \mathrm{~g} / \mathrm{l}$ sangat baik digunakan sebagai insektisida botani dalam mengendalikan populasi hama P.xylostella pada kondisi laboratorium, karena pada konsentrasi ini efektif mematikan sebesar 96,78\% seluruh populasi serangga yang diuji.

\section{PUSTAKA}

Anonim. 1994. Pedoman Pengenalan Pestisida Botani. Departemen Pertanian Direktorat Jenderal Perkebunan. Direktorat Bina Perlindungan Tanaman Perkebunan.

Badan Pusat Statistik Sulawesi Utara. 2015. Jumlah Rumah Tangga Usaha Holtikultura, Luas Tanam, dan Ratarata Luas Tanam Yang Diusahakan/ Dikelola per Rumah Tangga Menurut
Jenis Tanaman Holtikultura Semusim, 2013.

Corbet, J.R., K. Wright, A.C. Baillie. 1984. The Biochemical Mode of Action of Pesticides. Academic Press London.

Lim TK. 2012. Annona muricata. In: Edible Medicine and Non Medicine, Vol. 1 Fruts, Lim, T.K. (Edt). Dondhrect Holdberg London New York: Springer Science and Business Media BV, p. 190-200

Prijono, D. 1994. Pedoman Praktikum Teknik Pemanfaatan Insektisida Botanis. Bogor.

Sastroutomo, S. T. 1992. Pestisida DasarDasar dan Dampak Penggunaannya. PT. Gramedia Pustaka Utama. Jakarta.

Sembel, D.T., J. Pongoh, D. Kandowangko dan F. Kaseger. 1990. Pengkajian Penggunaan Pestisida di Sulawesi Utara. Kerjasama Dinas Pertanian Tanaman Pangan Dati I, Fakultas Pertanian Unsrat dan Bappeda Tkt I Sulut.

Trisnowati, B. A.,Setowati, A.E.,Priyo, S., 2012. Aktivitas Anti Makan EkstrakDaun Sirsak (Annona Muricata L.) dan Pengaruhnya Terhadap Indeks Nutrisi Seta Terhadap Struktur Membran Peritrofik Larva Instar V Spodoptera Litura F. J.HPT Tropika. Vol.2 (2): 164-176.

Wigglesworth, V.B. 1974. Insect Physiology. Chapman and Hall. London. 